\title{
Using the Motivated Strategies for Learning Questionnaire and the Strategy Inventory for Language Learning in Assessing Motivation and Learning Strategies of Generation 1.5 Korean Immigrant Students
}

\author{
Rosa Stoffa, Joseph C. Kush, and Misook Heo \\ Duquesne University, USA \\ Correspondence should be addressed to Misook Heo, heom@duq.edu
}

Received 6 September 2010; Accepted 3 December 2010

Academic Editor: Paul Lam

Copyright () 2011 Rosa Stoffa et al. This is an open access article distributed under the Creative Commons Attribution License, which permits unrestricted use, distribution, and reproduction in any medium, provided the original work is properly cited.

\begin{abstract}
This study examined the potential of utilizing the Motivated Strategies for Learning Questionnaire (MSLQ) and the Strategy Inventory for Language Learning (SILL) as instruments in measuring Generation 1.5 students' motivation and their use of language learning strategies. The MSLQ was of particular interest because it contains both a basic motivation subscale as well as a motivation/language learning strategies subscale. Participants of this study were 104 Generation 1.5 Korean immigrant students who were members of Korean communities located in Pittsburgh and Philadelphia, Pennsylvania. Participants provided general demographic information and completed both scales in a counterbalanced manner. Results indicated that while the two scales do have some similar content, the scales do not overlap entirely and appeared to measure two discrete indices. Results also indicated that a moderate correlation between MSLQ learning strategies and SILL learning strategies was found as well as between the SILL total score and the MSLQ total score.
\end{abstract}

\section{Introduction}

While there continues to be significant discussion on the role of motivation in second language (L2) learning, researchers generally agree that motivation is a principal determinant of L2 learning $[1,2]$. Previous research has evidenced a clear link between motivation and language learning; however, this relationship is not directly causal due to the influence of mediating factors such as self-efficacy, attributions, and achievement goals. While each of these factors contributes to the discussion, perhaps the most important consideration is the failure of previous research to fully account for the associated, underlying cognitive processes related with learner motivation and language learning. Interestingly, while many theoretical frameworks and standardized motivation instruments are available in general education [3], most of these instruments developed to assess L2 motivation have been by individual L2 researchers for their own study needs [4]. For example, over the past
30 years, numerous scales have been developed to assess motivation (e.g., Gardner's Attitude/Motivation Test Battery (AMTB), Pintrich et al's Motivated Strategies for Learning Questionnaire (MSLQ), and Kuhl's Action Control Scale (ACS-90)). Each of these instruments has advantages and disadvantages; Gardner's model is the only standardized instrument targeted for L2 learning, while the AMTB has been criticized for its inability to accurately assess the exact nature of the underlying learner trait because the instrument assesses both motivation and motivated behavior [5]. The lack of consensus surrounding standardized instruments for L2 motivation [6] has made it impossible to accurately compare results across studies and equally difficult to examine possible changes in motivation over time [4].

Likewise, while the positive impact of learning strategies in L2 learning has been acknowledged [7-10], researchers over the past three decades have rarely agreed on the term "language learning strategies" [11]; no consensus on a taxonomy of language learning strategies has been reached 
[12]; and the psychometric properties of the assessment instruments have thus been criticized (e.g., $[5,11]$ ). Making this situation more complicated, cultural background plays an important role in the use of students' language learning strategy [13]. Research has shown that Asian students use different language learning strategies than students from other cultural backgrounds $[14,15]$. For example, Chinese students frequently use compensation strategies whether they are studying in Mainland China, Taiwan, or in the United States. In contrast, memory strategies are used infrequently among Chinese students and Korean students. Social strategies are also generally unpopular among Chinese and Japanese subjects. Clearly, cultural factors play an important role in the selection of language learning strategies.

Students who are capable of monitoring their own metacognitive processes can control their learning by applying individualized cognitive strategies in their own learning. Within the framework of metacognition, cognitive learning strategies play a major role by providing methods for students to gain higher academic achievement. Research on cognitive strategies has demonstrated a significant correlation between cognitive learning strategies and academic performance, including language learning $[16,17]$. Clearly educators, as well as students, must learn how the use of personalized cognitive strategies contributes to language learning.

The current study examined the potential of utilizing the Motivated Strategies for Learning Questionnaire (MSLQ) and the Strategy Inventory for Language Learning (SILL) as instruments in assessing the motivation and language learning strategies of immigrant adolescents. Immigrant adolescents, especially those who were foreign-born, but grew up in countries speaking languages other than their native language, are forced to learn the languages and the cultures of both settings. These immigrant adolescents, often identified as Generation 1.5 [18], learn English through natural interaction rather than through formal classes [19], are partially foreign educated [20], and typically have graduated from high schools in the English speaking western country that they are resident, thus are somewhat familiar with academic systems of the resident country [20, 21]. With this background, Generation 1.5 students exhibit different characteristics from both their parents' generation (first generation) as well as their offspring's generation (second generation). For example, unlike the first generation, the social English of Generation 1.5 students is fluent like the second generation; their academic English is, however, oftentimes not as fluent as second generation immigrants [22]. As Asher et al. [23] indicated, Cognitive Academic Language Proficiency (CALP) is cognitively more demanding than Basic Interpersonal Communication Skills (BICS), and without CALP skills, students are not able to be academically successful.

Despite the growing numbers of immigrant students who have enrolled in United States colleges (26.7\%) [24], few studies have examined the effectiveness of the learning strategies and motivation these students have adopted in their efforts to improve academic success. To date, most research related to immigrant children has focused upon English language acquisition in K-12, L2 education [21].
Among generation 1.5, Korean immigrant college students are the special interest subgroup of this study. As of 2007, Korean immigrants, estimated at approximately 1.04 million, are the seventh-largest foreign-born group in the United States, and about 25\% of this population arrived in 2000 or later [25]. This finding clearly reflects their rapid growth in recent years. According to data from the U.S. Census Bureau [24], the majority (69.6\%) of Korean immigrants speak a language other than English at home, and Korean immigrants exhibit a higher educational achievement $(48.8 \%$ possess a Bachelor's degree or higher compared to the national average of $27.7 \%$ ) than the overall immigrant population.

Korean's worldview is often influenced by Confucianism, which provides students with a strong cultural value emphasizing the importance of education; providing the best possible education to their children is norm in Korean society. For example, Korean parents are typically willing to take out a personal loan from the bank to pay for their children's private university education. Kim [26] points out that education is considered an essential obligation of Korean parents. Confucian philosophy is also very influential in Korean family values. The analysis of cultural influence regarding parents' high expectation of their children's academic achievement has been a common factor of Korean students' academic success. Another aspect of contributing academic success of Korean students involves their obligations based on Confucian value system. Korean children's obligations to their parents are to achieve the greatest education possible [26]. In addition, Korean students tend to follow their parents' expectations and are highly motivated not only to have the approval of their parents but also to have material concerns such as job prospects.

\section{Motivated Strategies for Learning Questionnaire (MSLQ) and Strategy Inventory for Language Learning (SILL)}

In assessing students' motivation and their use of learning strategies, the MSLQ has been used by researchers and instructors around the world [27]. While the scale has not been widely applied in language learning, it has been demonstrated that the instrument can be easily applied to language learning [16]. In assessing students' language learning strategies, the most widely used instrument developed is the Strategy Inventory for Language Learning (SILL). The most recent revision of the SILL provides a version for students who speak English as a Second Language (ESL)/English as a Foreign Language (EFL). The ESL/EFL SILL has been referred to as "the most comprehensive classification of learning strategies to date" [28, p. 539] and is the most frequently used scale of this type in use around the world, with multiple immigrant populations.

\subsection{Motivated Strategies for Learning Questionnaire (MSLQ).} The Motivated Strategies for Learning Questionnaire (MSLQ), developed by Pintrich and his colleagues, is a widely used self-report instrument designed to assess college 
students' motivational orientations and their use of different learning strategies [29]. This 81-item instrument, 7-point Likert scale $(1=$ not at all true of me and $7=$ very true of me $)$ consists of six motivation scales (31 items measuring value, expectancy, and affective component) and nine learning strategies (50 items measuring cognitive and metacognitive strategies, and resource management strategies). This instrument has been widely used in measuring critical thinking in learning, motivation for conceptual change, self-efficacy, beliefs about knowledge, intrinsic and extrinsic motivation, integrated metacognitive instruction, adolescent help-seeking in math classes, and goal orientation, and it has been found that most components of the MSLQ are correlated with multiple aspects of motivation and learning strategies $[27,30]$.

The MSLQ has undergone extensive psychometric development, and the overall internal consistency reliability, Cronbach alphas, provided by Pintrich et al. [29] has been found to be adequate (.78 and .71 for motivation scales and learning strategies, resp.). Other researchers have shown similar internal consistency reliability estimates for the MSLQ with independent samples [4, 31]. Beyond English, the MSLQ has been widely translated into other languages including Greek [32], Hebrew [33], Korean [34, 35], Norwegian [36], German [37], and Chinese [17, 38-40].

2.2. Strategy Inventory for Language Learning (SILL). The Strategy Inventory for Language Learning (SILL) is designed to examine students' reported frequency of use of six systems of language learning strategies. The six systems, proposed by Oxford [41], include three direct language learning strategies (cognitive, memory, and compensatory strategies) and three indirect language learning strategies (metacognitive, affective, and social strategies). The scale has also been shown to evidence adequate indices of reliability and validity [8]; cronbach alphas have been shown to be.94 for the entire scale [42]. Additionally, a number of studies have shown support for the criterion-related validity of the instrument (e.g., [43]).

The ESL/EFL version of the SILL has similarly produced Cronbach alpha reliability coefficients above .90 in Chinese, Japanese, Korean, and Puerto Rican Spanish translations [44]. The ESL/EFL version of the SILL's validity has also been evidenced in many research projects examining content validity and criterion-related validity [8].

The current SILL provides a version for students who speak English as a Second Language (ESL)/English as a Foreign Language (EFL) which includes 50 items, purported to assess six domains: nine items in memory strategies, 14 items measuring cognitive strategies, six items measuring compensation strategies, nine items measuring metacognitive strategies, six items measuring affective strategies, and six items measuring social strategies. Additionally, a similar version for native speakers of English who are learning a foreign language ( 80 item questionnaire) has also been produced. The SILL has been translated into many languages and has been utilized for language learners in higher education and government agencies around the world [9]. Given the prevalent use of the SILL, the scale has been extensively examined in L2 acquisition regarding language strategy use [2].

\section{Research Hypotheses}

To examine the potential of utilizing the Motivated Strategies for Learning Questionnaire (MSLQ) and the Strategy Inventory for Language Learning (SILL) in combination as instruments examining Generation 1.5 students' motivation and their use of language learning strategies, the following research hypotheses were created.

(1) There will be a positive, significant relationship between language learning strategy and motivation with a population consisting of Generation 1.5 Korean college students.

(2) There will be a positive, significant relationship between the MSLQ learning strategies and the SILL learning strategies with a population consisting of Generation 1.5 Korean college students.

(3) There will be a positive, significant relationship between the MSLQ total scores and the SILL total scores with a population of Generation 1.5 Korean college students.

\section{Research Methodology}

4.1. Instruments. As indicated previously, the two main research instruments were the MSLQ and the SILL scales. In addition, a demographic questionnaire was created by the researchers to obtain participants' background information relevant to their involvement in this study (i.e., age, age of immigration, length of residence, ESL levels, and high school GPA). Students completed both scales, during a single administration, in counterbalanced order.

4.2. Participants. Generation 1.5, Korean, immigrant college students from universities located in Pittsburgh and Philadelphia, Pennsylvania participated in the study. While 117 students agreed to participate in the study, only 104 students were accepted as final participants for the study as 13 students did not fully meet the Generation 1.5 Korean immigrant criteria. At the time of the study, all the participants were enrolled in higher education institutions. The target age of the participants was over 18 years old (71\%: 24 years of age or younger, 17.5\%: between 25 and 30 years old, and $11.5 \%$ : over 30 years old) and the majority came to the United States when they were teenagers (61.5\%: 12 and 18 years, $18.2 \%$ : younger than 12 years old, and $20.2 \%$ did not identify their age of immigration). Participants' length of residence ranged from 1 to 20 years $(24.8 \%$ : less than 5 years, 48.5\%: between 5 and 10 years, and 26.7\%: over 10 years). The majority of participants (49\%: advanced) identified themselves as advanced ESL learners, whereas 10 (9.6\%) identified themselves as ESL beginners. Although high school GPAs were not reported by all students, the average combined score for students who did report was 3.672, reflecting the high achievement typically associated with Korean immigrant students. 
4.3. Data Analysis. Descriptive statistics were calculated on participant's demographic information. Additionally, Pearson correlation coefficients were utilized to determine significant correlations for each pair of data. The significance level was determined a priori to be $P<.05$.

\section{Results}

5.1. Descriptive Analysis of MSLQ and SILL. Participant responses to each of the MSLQ and SILL item are presented in Tables 1 and 2. Table 1 demonstrates that the 31 MSLQ motivation items evidenced mean scores between 3.60 and 5.75, with standard deviations between 1.21 and 2.02. Additionally, when examining the 50 MSLQ learning strategy items, mean scores ranged between 3.16 and 5.63, with standard deviations between 1.35 and 1.96. When considering the six categories of MSLQ Motivation, Task value, and Control of learning beliefs were evidenced the most by the Generation 1.5 Korean immigrant college students (mean of 5.19 and 5.25, resp.) while Intrinsic goal orientation and Test anxiety were evidenced the least (mean of 4.88 for both). Finally, among the nine categories of MSLQ Learning strategies, Rehearsal, Elaboration, and Organization were utilized the most by the Generation 1.5 Korean immigrant college students (means of 4.76, 4.67, and 4.66, resp.) while Peer learning was utilized the lest (mean of 3.50).

An examination of Table 2 indicates that for the 50 SILL items, mean scores ranged from 2.02 to 3.91, with standard deviations between 1.05 and 1.48 . The relatively small standard deviations indicate that responses were clustered closely around the mean. Among the six components of the SILL posited by Oxford, Table 2 also indicates that Compensatory and Cognitive strategies were utilized the most frequently by the Generation 1.5 Korean immigrant college students, while Affective and Memory strategies were evidenced the least often.

5.2. Pearson Correlation Coefficients for MSLQ and SILL. The first comparison of the two measures examined the correlations between all indices of the MSLQ and SILL. Cronbach alphas for the MSLQ and SILL scales from the current sample were 0.910 and 0.936 , respectively, showing strong internal consistencies. Correlations among these scores of the MSLQ and SILL are shown in Table 3.

Regarding the first research hypothesis, it was expected that there would be a significant, positive relationship between language learning strategies and motivation. Results produced a moderately, statistically significant correlation between the MSLQ Motivation and the MSLQ Learning Strategies $(r=.46)$. In addition, there was a somewhat lower correlation between the MSLQ Motivation subscale and the SILL Indirect Learning Strategies $(r=.22)$; and the MSLQ Motivation subscale failed to significantly correlate with the SILL Direct Learning Strategies $(r=.17)$. Results indicated that while the two scales do have some similar content, the scales do not overlap entirely and do appear to measure two discrete indices.

The second research hypothesis predicted that there would be a positive, significant relationship between the
TABLe 1: Descriptive statistics of motivated strategies for learning questionnaire (MSLQ) for Korean American students ${ }^{1}$.

\begin{tabular}{|c|c|c|c|}
\hline Scales & Sub-scales & Mean & $\mathrm{SD}$ \\
\hline \multirow{6}{*}{$\begin{array}{l}\text { Motivation } \\
\text { scales }\end{array}$} & $\begin{array}{l}\text { Intrinsic goal } \\
\text { orientation }\end{array}$ & 4.88 & 1.509 \\
\hline & $\begin{array}{l}\text { Extrinsic goal } \\
\text { orientation }\end{array}$ & 4.99 & 1.578 \\
\hline & Task value & 5.19 & 1.413 \\
\hline & $\begin{array}{l}\text { Control of learning } \\
\text { beliefs }\end{array}$ & 5.25 & 1.471 \\
\hline & $\begin{array}{l}\text { Self-efficacy for } \\
\text { learning and } \\
\text { performance }\end{array}$ & 4.9 & 1.317 \\
\hline & Test anxiety & 4.88 & 1.729 \\
\hline \multirow{9}{*}{$\begin{array}{l}\text { Learning } \\
\text { strategy } \\
\text { scales }\end{array}$} & Rehearsal & 4.76 & 1.665 \\
\hline & Elaboration & 4.67 & 1.619 \\
\hline & Organization & 4.66 & 1.690 \\
\hline & Critical thinking & 4.36 & 1.518 \\
\hline & $\begin{array}{l}\text { Metacognitive } \\
\text { self-regulation }\end{array}$ & 4.46 & 1.593 \\
\hline & $\begin{array}{l}\text { Time and study } \\
\text { environment } \\
\text { management }\end{array}$ & 4.48 & 1.717 \\
\hline & Effort regulation & 4.15 & 1.722 \\
\hline & Help seeking & 4.53 & 1.772 \\
\hline & Peer learning & 3.5 & 1.762 \\
\hline
\end{tabular}

Note: ${ }^{1}$ Minimum and maximum scores are based on 7-point Likert scale (1: Not at all and 7: Very true of me).

TABle 2: Descriptive Statistics of Strategy Inventory for Language Learning (SILL) ${ }^{1}$.

\begin{tabular}{lcc}
\hline Systems & Mean & SD \\
\hline Memory strategies & 3.02 & 1.307 \\
Cognitive strategies & 3.45 & 1.248 \\
Compensatory strategies & 3.50 & 1.193 \\
Meta cognitive strategies & 3.28 & 1.242 \\
Affective strategies & 2.78 & 1.273 \\
Social strategies & 3.19 & 1.277 \\
\hline
\end{tabular}

Note: ${ }^{1}$ Five-point Likert scale was used (1: Never or almost never true of me; 2: Usually not true of me; 3: Somewhat true of me; 4: Usually true of me; and 5. Always or almost always true of me).

MSLQ learning strategies and the SILL learning strategies. As expected, results showed that there was a moderately, statistically significant correlation between the MSLQ Learning Strategies and the two types of scores (Direct/Indirect Strategies) produced by the SILL ( $r=.32$ and .33 , resp.).

Regarding the final research hypothesis, it was predicted that there would be a positive, significant relationship between the MSLQ total scores and the SILL total scores. Again, the findings showed a moderate correlation between the SILL total scores and the MSLQ total scores $(r=.35)$, supporting the research hypothesis. 
TABLE 3: Pearson correlation coefficients for MSLQ and SILL.

\begin{tabular}{|c|c|c|c|c|c|}
\hline & MSLQLS $^{1}$ & MSLQTotal $^{2}$ & SILLDirect $^{3}$ & SILLIndirect $^{4}$ & SILLTotal \\
\hline MSLQMot & $.460^{* *}$ & $.749^{* *}$ & .170 & $.220^{*}$ & $.210^{*}$ \\
\hline MSLQLS & & $.933^{* *}$ & $.324^{* *}$ & $.331^{* *}$ & $.355^{* *}$ \\
\hline MSLQTotal & & & $.310^{* *}$ & $.336^{* *}$ & $.350^{* *}$ \\
\hline SILLDirect & & & & $.698^{* *}$ & $.931^{* *}$ \\
\hline SILLIndirect & & & & & $.911^{* *}$ \\
\hline
\end{tabular}

Note: ${ }^{1}$ MSLQMot: MSLQ Motivation subscale.

${ }^{2}$ MSLQLS: MSLQ Learning Strategies subscale.

${ }^{3}$ SILLDirect: SILL Direct Strategies.

${ }^{4}$ SILLIndirect: SILL Indirect Strategies.

* Correlation is significant at the 0.05 level (2-tailed).

${ }^{* *}$ Correlation is significant at the 0.01 level (2-tailed).

\section{Discussion}

The primary goal of this study was to examine the relationship between motivation and language learning strategies in a population of Generation 1.5, Korean students. Specifically, two of the most commonly administered scales used with L2 learners were examined to better understand the possible relationship overlap between the constructs of motivation and language learning strategies. Two main conclusions were evidenced which offer important theoretical as well as practical implications.

First, results showed that the motivational subscale of the MSLQ was moderately correlated with both subscales of the SILL. The MSLQ was chosen intentionally because it contains two subscales including a "pure" motivation subscale as well as a motivation/language learning strategies subscale. While no correlation was found between motivation and direct language learning strategies, a significant relationship was evidenced between motivation and indirect language learning strategies. The relationship between motivation and language learning strategies has been previously established; however, our results highlight the complexity of this relationship. The stronger relationship between motivation and indirect language learning strategies is crucial when placed within a metacognitive framework. In all L2 learning situations, students are expected to identify and self-regulate the individualized processes that they believe work the best for them. This practice is even more critical for Generation 1.5 students who share some similarities in the identification of these processes with traditional immigrant students yet also maintain unique characteristics. Results from this study show that the current sample of Generation 1.5 Korean students seem to be able to maintain this balance. This finding is particularly important, as previous research has shown that Generation 1.5 students are increasingly being sent to school without adequate English as a Second Language (ESL) education [21].

An analysis of the Motivation and Learning strategies used by the students produced several interesting findings. The high Control of learning belief score reflects the expectation by the students that an effort to learn will produce positive outcomes. These outcomes are also more dependent upon intrinsic factors such as one's own effort, than external factors such as a teacher. Relatedly, Task value (the perception of the course material in terms of interest and importance) was also scored high by the 1.5 students reflecting the very practical, applied nature of their motivation. This finding is further reflected by the high Metacognitive self-regulation and Time and study environment management scores produced on the Learning strategies section of the MSLQ.

With regards to the current sample of L2 learners, several unique strategies appeared to emerge: Compensatory and Cognitive techniques (e.g., Questions 15, I watch English language TV shows spoken in English or go to movies spoken in English; 17, I write notes, messages, letters, or reports in English; 24, To understand unfamiliar English words, I make guesses, and 29, If I can't think of an English word, I use a word or phrase that means the same thing) represented the strategies most frequently used by the Generation 1.5 students. It is interesting to note that each of these strategies was done in isolation and not in an interactive or conversational setting. It is also interesting that these techniques were all applied in nature and minimized or ignored rote memorization techniques such as using flashcards or repeating unfamiliar words "over and over." While this last finding is less surprising given that Generation 1.5 students would typically have advanced language abilities making the rote memory techniques used in the initial learning of a language less necessary, the finding that these students practiced their language skills in isolation (e.g., while watching TV or when writing notes or letters) may reflect conflicting identities with both first and second generations.

The current study also contributes to the existing educational research literature by supporting previous research on L2 learning. Ultimately, the present study appears to have identified an important indicator of educational practice for L2 learning through the combination of the MSLQ and the SILL. As would be expected, indirect and direct language learning skills evidenced the strongest relationship among the examined variables. While language learning skills relate to motivation, however, they should most likely be thought of as a relatively unique construct. When considering language learning strategies, the use of individualized 
strategies has been shown to enhance language proficiency $[16,45]$. Specifically, the difference between successful and less successful learners is typically the learners' capability of applying strategies in their own learning situations [10]. Students with different levels of language proficiency make different use of underlying skills [46].

Additionally, current findings offer important implications for university faculty who work with Generation 1.5 populations as well as suggestions for future research. First, educators may need to re-examine their practices involving language learning strategies and motivation of special student populations. The current results suggest a distinction between language learning strategies that relate to motivation and more discrete, indirect language skills. The acknowledgment of this distinction should assist educators in producing more individualized strategies for their L2 learning students. Ultimately, this study also offers a new direction for $\mathrm{L} 2$ research, because the intended use of combining both MSLQ and SILL for this study was to expose the complexity of the L2 learning process. Considering the fact that academic success is strongly influenced by individual differences in motivation [47], educators who work with Generation 1.5 students must continue to more carefully define the specific strategies that are used by these students. For example, university instructors should attempt to better understand the specific language learning strategies their L2 students use and encourage lower proficiency students to use more appropriate language learning strategies in their learning process. Similarly, as instructors become more aware of the successful strategies used by their students, these practices should be incorporated into their lessons to better facilitate the learning styles of their students.

An additional implication of this study is that researchers must continue to better understand the complexity of L2 student academic experiences and learning backgrounds in higher education, and subsequently expand theoretical frameworks. Research in Generation 1.5 immigrant students' academic experiences is an unavoidable field regarding the study of individual differences. Given the report from the US Census Bureau [24] regarding Korean immigrants' higher educational achievement, Asian American academic success and achievement is viewed as the "model minority". Asian American youth have been described with the image drawn from the model minority [48]. Researchers are recommended to focus more attention on the specific cultural values and behaviors related to the generational status of immigrant students.

The current study is not without limitations. It is important to note that the survey instrument utilized in the current study was administered only to participants who attended Korean churches located in Pittsburgh and Philadelphia. Korean churches were chosen because majority of Korean immigrants in the United States are members of Korean ethnic churches, and these churches serve a major social function for Korean community as a whole $[49,50]$. While the current study did not examine whether different denominations of churches or socioeconomic statuses of families are potential covariates, these considerations are advised for future researchers. It is also important to recognize that all data were collected from self-reports; no attempt was made to directly measure motivation or learning strategies as they were actually employed in the classroom. Future research may consider observing these behaviors within the classroom or obtaining reports from the classroom instructors regarding the frequency of their occurrence.

\section{References}

[1] Z. Dörnyei, K. Csizer, and N. Nemeth, Motivation, Language Attitudes, and Globalization: A Hungarian Perspective, Multilingual Matters, Clevedon, UK, 2006.

[2] R. C. Gardner, P. F. Tremblay, and A. M. Masgoret, "Towards a full model of second language learning: an empirical investigation," The Modern Language Journal, vol. 81, pp. 344$362,1997$.

[3] D. H. Schunk, P. R. Pintrich, and J. Meese, Motivation in Education: Theory, Research, and Applications, Prentice Hall, Englewood Cliffs, NJ, USA, 3rd edition, 2007.

[4] S. C. Huang, "Assessing motivation and learning strategies using the motivated strategies for learning questionnaire in a foreign language learning context," Social Behavior and Personality, vol. 36, no. 4, pp. 529-534, 2008.

[5] Z. Dörnyei, The Psychology of the Language Learner: Individual Differences in Second Language Acquisition, Lawrence Erlbaum, Mahwah, NJ, USA, 2005.

[6] Z. Dörnyei, Teaching and Researching Motivation, Pearson Education, Harlow, UK, 2001.

[7] E. Macaro, "Strategies for language learning and for language use: revising the theoretical framework," Modern Language Journal, vol. 90, no. 3, pp. 320-337, 2006.

[8] R. L. Oxford and J. A. Burry-Stock, "Assessing the use of language learning strategies worldwide with the ESL/EFL version of the strategy inventory for language learning (SILL)," System, vol. 23, no. 1, pp. 1-23, 1995.

[9] R. Oxford and M. Nyikos, "Variables affecting choice of language learning strategies by university students," Modern Language Journal, vol. 73, pp. 291-399, 1989.

[10] R. J. Vann and R. G. Abraham, "Strategies of unsuccessful learners,” TESOL Quarterly, vol. 24, pp. 177-198, 1990.

[11] Z. Dörnyei and P. Skehan, "Individual difference in second language learning," in Handbook of Second Language Acquisition, C. Doughty and M. Long, Eds., pp. 589-630, Blackwell, Oxford, UK, 2003.

[12] C. Griffiths, "Language learning strategies: theory and research," Research paper series, 2004, http://www.crie.org.nz/ research_paper/c_griffiths_op1.pdf.

[13] R. L. Oxford, "Employing a questionnaire to assess the use of language learning strategies," Applied Language Learning, vol. 7, no. 1-2, pp. 25-35, 1996.

[14] C. Griffiths, "Patterns of language learning strategy use," System, vol. 31, no. 3, pp. 367-383, 2003.

[15] R. L. Politzer and M. McGroarty, "An exploratory study of learning behaviors and their relationship to gains in linguistic and communicative competence," TESOL Quarterly, vol. 19, pp. 103-124, 1985.

[16] P. D. MacIntyre, K. MacMaster, and S. Baker, "The convergence of multiple models of motivation for second language learning: Gardner, Pintrich, Kuhl and McCroskey," in Montivation and Second Language Acquisition, Z. Dörnyei and R. Schmidt, Eds., pp. 461-492, Second Language Teaching and Curriculum Center, The University of Hawaii, Honolulu, Hawaii, USA, 2001. 
[17] J. Sachs, Y. K. Law, C. K. K. Chan, and N. Rao, "A nonparametric item analysis of the motivated strategies for learning questionnaire-Chinese version," Psychologia, vol. 44, no. 3, pp. 197-208, 2001.

[18] R. G. Rumbaut and K. Ima, "The adaptation of Southeast Asian refugee youth. A comparative study," Final report to the Office of Resettlement (ED Identification 299372, 1988, http://eric.ed.gov/ERICWebPortal/contentdelivery/servlet/ ERICServlet?accno=ED299372.

[19] N. Destandau and M. Wald, "Promoting Generation 1.5 learners' academic literacy and autonomy: contributions from the learning center," CATESOL Journal, vol. 14, no. 1, pp. 207234, 2002.

[20] M. Roberge, "Working with generation 1.5 students writers in college composition," in Proceedings of the Conference on College Composition and Communication, San Francisco, Calif, USA, 2005.

[21] L. Harklau, K. Losey, and M. Siegal, Eds., Generation 1.5 Meets College Composition: Issues in the Teaching of Writing to U.S.-Educated Learners of ESL, Lawrence Erlbaum Associates, Mahwah, NJ, USA, 1999.

[22] S. N. Forrest, "Three foci of an effective high school generation 1.5 literacy program," Journal of Adolescent and Adult Literacy, vol. 50, no. 2, pp. 106-112, 2006.

[23] C. Asher, E. Case, and Y. Zhong, "Serving generation 1.5: Academic Library use and Studens from Non-English-Speaking Households," College \& Research Libraries, pp. 258-272, May 2009.

[24] U.S. Census Bureau, "United States-Selected Population Profile in the United States," 2008, http://factfinder.census. gov/servlet/IPTable?_bm=y\&-context=ip\&-reg=ACS_2008_ 1YR_G00_S0201:400;ACS_2008_1YR_G00_S0201PR:400;ACS_ 2008_1YR_G00_S0201T:400;ACS_2008_1YR_G00_S0201TPR: 400\&-qr_name=ACS_2008_1YR_G00_S0201\&-qr_name=ACS_ 2008_1YR_G00_S0201PR\&-qr_name=ACS_2008_1YR_G00_ S0201T\&-qr_name=ACS_2008_1YR_G00_S0201TPR\&-ds_ name=ACS_2008_1YR_G00_\&-tree_id=306\&-redoLog=false\& -geo_id=01000US $\&$-search_results $=01000$ US $\&$-format $=\&$ lang=en.

[25] A. Terrazas, "Korean Immigrants in the United States," http:// www.migrationinformation.org/USfocus/print.cfm?ID=716.

[26] H. C. Kim, Korean-American Youth Identity and 9/11: An Examination of Korean-American Ethnic Identity in Post- 9/11 America, Hermit Kingdom Press, Highland Park, NJ, USA, 2008.

[27] T. G. Duncan and W. J. McKeachie, "The making of the motivated strategies for learning questionnaire," Educational Psychologist, vol. 40, no. 2, pp. 117-128, 2005.

[28] R. Ellis, The Study of Second Language, Oxford University, New York, NY, USA, 1994.

[29] P. R. Pintrich, D. Smith, T. Garcia, and W. J. McKeachie, A Manual for the Use of the Motivated Strategies for Learning Questionnaire, National Center for Research to Improve Postsecondary Teaching and Learning, University of Michigan, Ann Arbor, Mich, USA, 1991.

[30] J. N. Bassili, "Motivation and cognitive strategies in the choice to attend lectures or watch them online," Journal of Distance Education, vol. 22, no. 3, pp. 129-148, 2008.

[31] A. M. Kosnin, "Self-regulated learning and academic achievement in Malaysian undergraduates," International Education Journal, vol. 8, no. 1, pp. 221-228, 2007.
[32] E. Andreou and P. Metallidou, "The relationship of academic and social cognition to behaviour in bullying situations among Greek primary school children," Educational Psychology, vol. 24, no. 1, pp. 27-41, 2004.

[33] Y. Eshel and R. Kohavi, "Perceived classroom control, selfregulated learning strategies, and academic achievement," Educational Psychology, vol. 23, no. 3, pp. 249-260, 2003.

[34] M. Bong, "Between- and within-domain relations of academic motivation among middle and high school students: selfefficacy, task-value, and achievement goals," Journal of Educational Psychology, vol. 93, no. 1, pp. 23-34, 2001.

[35] M. Bong and D. Hocevar, "Measuring self-efficacy: multitraitmultimethod comparison of scaling procedures," Applied Measurement in Education, vol. 15, no. 2, pp. 143-171, 2002.

[36] Y. Ommundsen, "Implicit theories of ability and selfregulation strategies in physical education classes," Educational Psychology, vol. 23, no. 2, pp. 141-157, 2003.

[37] H. Neber and K. A. Heller, "Evaluation of a summer-school program for highly gifted secondary-school students: the German Pupils Academy," European Journal of Psychological Assessment, vol. 18, no. 3, pp. 214-228, 2002.

[38] N. Rao and J. Sachs, "Confirmatory factor analysis of the Chinese version of the motivated strategies for learning questionnaire," Educational and Psychological Measurement, vol. 59, no. 6, pp. 1016-1029, 1999.

[39] N. Rao, B. E. Moely, and J. Sachs, "Motivational beliefs, study strategies, and mathematics attainment in high- and lowachieving Chinese secondary school students," Contemporary Educational Psychology, vol. 25, no. 3, pp. 287-316, 2000.

[40] J. Sachs, Y.-K. Law, and C. K. K. Chan, "An analysis of the relationship between the motivated strategies for learning questionnaire and the learning process questionnaire," Psychologia, vol. 45, no. 3, pp. 193-203, 2002.

[41] R. L. Oxford, Language Learning Strategies: What Every Teacher Should Know, Newbury House, New York, NY, USA, 1990.

[42] T. Y. Hsiao and R. L. Oxford, "Comparing theories of language learning strategies: a confirmatory factor analysis," The Modern Language Journal, vol. 2, pp. 368-383, 2002.

[43] J. C. Anderson and D. W. Gerbing, "Structural equation modeling in practice: a review and recommended two-step approach," Psychological Bulletin, vol. 103, no. 3, pp. 411-423, 1988.

[44] R. Oxford, Ed., Language Learning Strategies around the World: Cross-Cultural Perspectives, Second Language Teaching and Curriculum Centre, University of Hawaii Press, Honolulu, Hawaii, USA, 1996.

[45] C. C. M. Goh, "How ESL learners with different listening abilities use comprehension strategies and tactics," Language Teaching Research, vol. 2, no. 2, pp. 124-147, 1998.

[46] S. Ross and M. Rost, "Learner use of strategies in interaction: typology and teachability," Language Learning, vol. 41, no. 2, pp. 235-273, 1991.

[47] M. Komarraju, S. J. Karau, and R. R. Schmeck, "Role of the Big Five personality traits in predicting college students' academic motivation and achievement," Learning and Individual Differences, vol. 19, pp. 47-52, 2009.

[48] J. C. Ng, S. S. Lee, and Y. K. Pak, "Contesting the model minority and perpetual foreigner stereotypes: a critical review of literature on Asian Americans in education," Review of Research in Education, vol. 31, pp. 95-130, 2007. 
[49] P. G. Min, "The structure and social functions of Korean immigrant churches in the United States," International Migration Review, vol. 26, no. 4, pp. 1370-1394, 1992.

[50] P. G. Min and J. H. Kim, Eds., Religions in Asian America: Building Faith Communities, AltaMira Press, Walnut Creek, Calif, USA, 2002. 


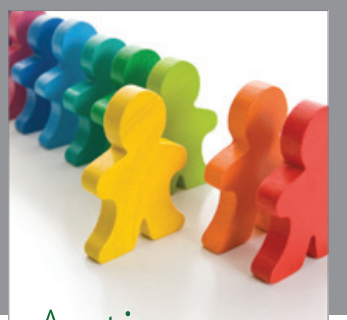

Autism

Research and Treatment
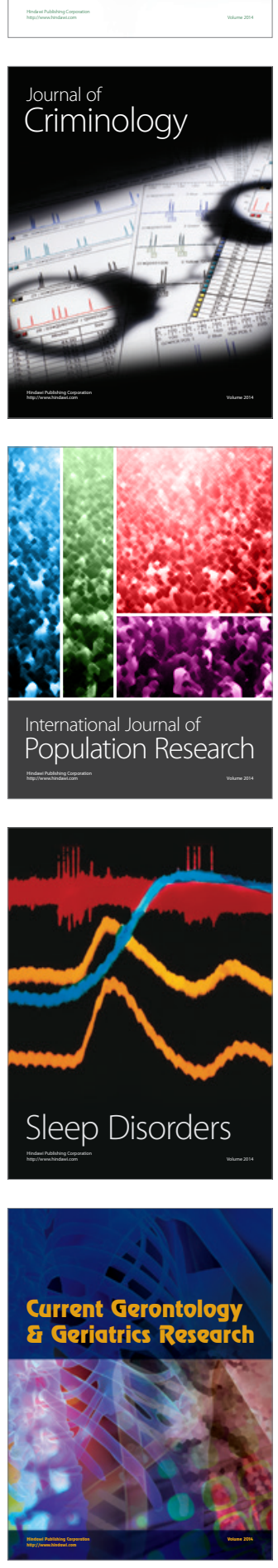
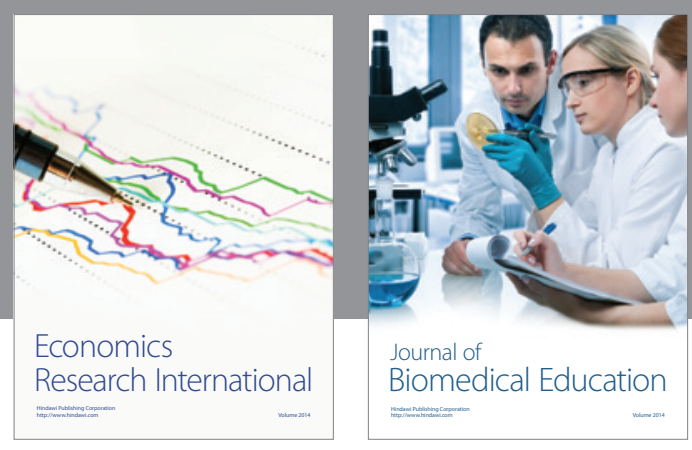

Journal of

Biomedical Education

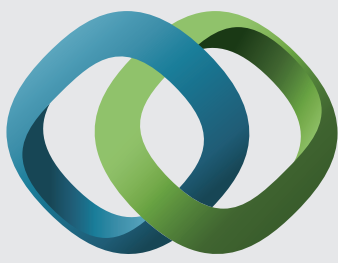

\section{Hindawi}

Submit your manuscripts at

http://www.hindawi.com
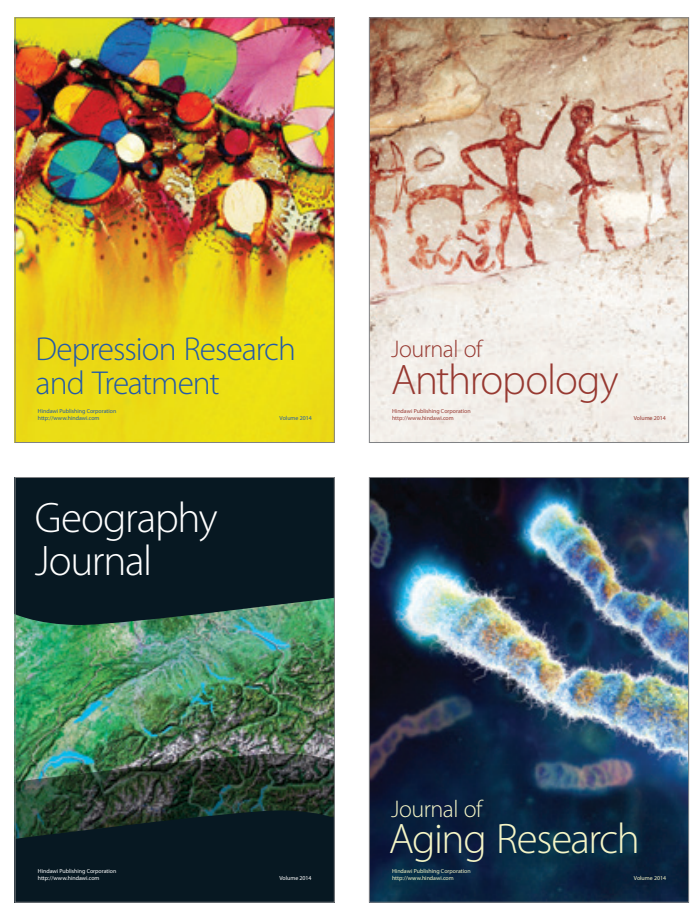

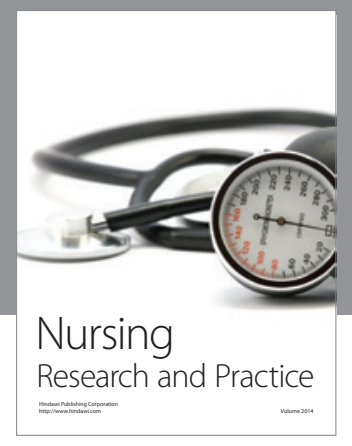

Nursing

Research and Practice

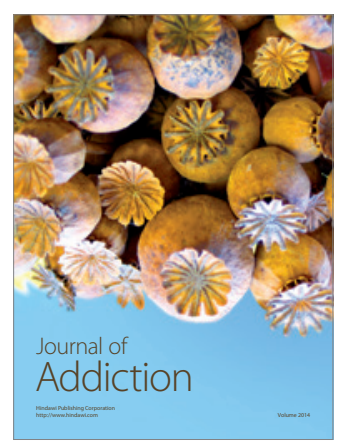

Child Development

Research

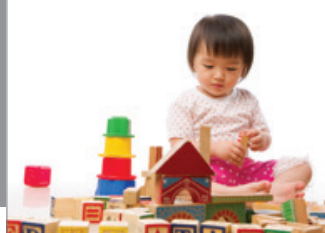

迥
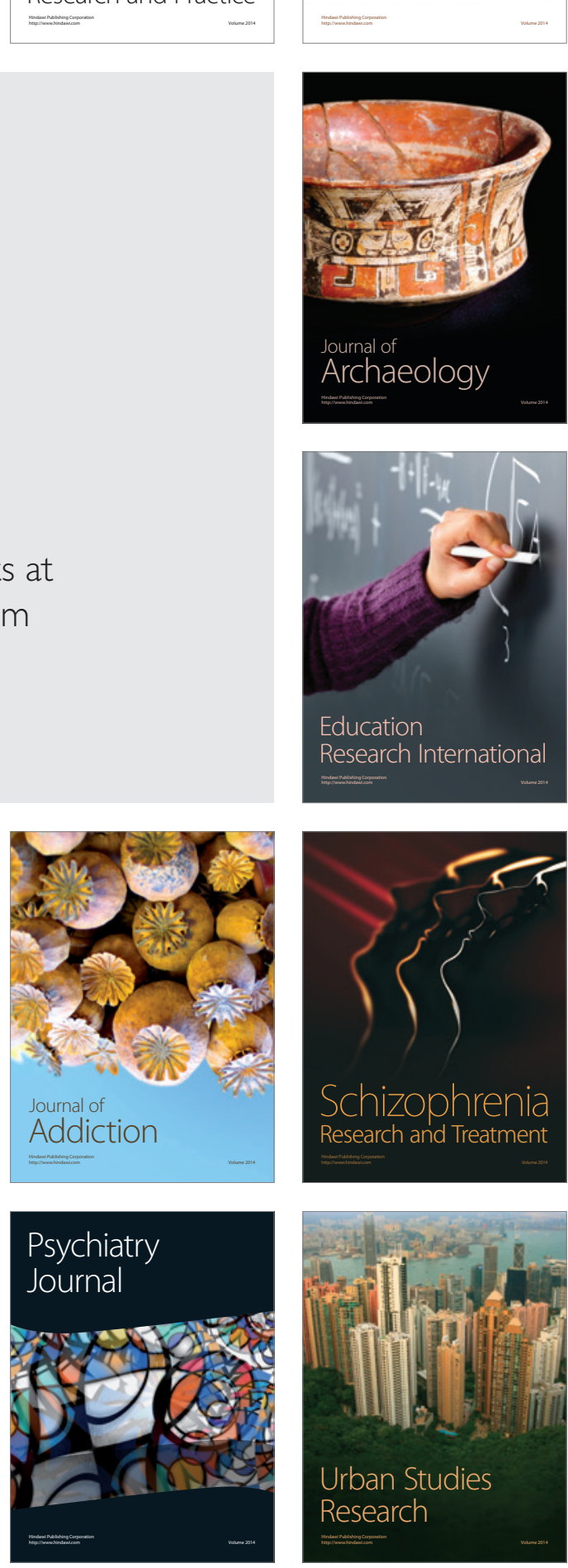